\title{
Assessment of risky sexual behavior and practice among Aksum University students, Shire Campus, Shire Town, Tigray, Ethiopia, 2017
}

\author{
Awoke Kebede*, Bogale Molla and Hadgu Gerensea
}

\begin{abstract}
Objective: Having sex at early age, having multiple sexual partners, having sex while under the influence of alcohol or drugs and unprotected sexual behaviors are the common characteristics of risky sexual behavior which increases risk of individuals to sexuality and reproductive health problems. Risky sexual behavior is the most common problem in adolescents and young adults which may expose individuals for permanent social, economical, psychological and physical problem. So that this study focus on assessment of risk sexual behavior using institution based cross-sectional study design on 287 randomly selected subjects among Aksum University students.

Results: Almost 60\% students reported to have ever had sexual activity. Of which 86 (83.5\%) and 112 (64.4\%) reported having inconsistent condom use and multiple sexual partners respectively. Even though more than half of first sexual intercourse (61.5\%) starts due to their desire but still peer pressure and alcohol have significant effect. Similarly the study indicated that a significant segment of students have risk sexual behaviors which increase individuals' risk of acquiring HIV/AIDS. Unless appropriate age and institutional targeted interventions exist, certain behaviors can place the university students at greater risk of HIV infection and sexually transmitted disease.
\end{abstract}

Keywords: Risk sexual behavior, Students, Ethiopia

\section{Introduction}

Risk sexual behavior is commonly defined as behavior that increases susceptibility of an individual to problems related to sexuality and reproductive health. They include having sex at an early age, having multiple sexual partners, having sex while under the influence of alcohol or drugs and unprotected sexual behaviors [1, 2]. Current statistics on HIV/AIDS indicate that one-half of all new HIV infections worldwide occur among young people ages 15-24. Every minute, five young people worldwide become infected with HIV/AIDS [3].

The trends in sexual activity younger ages are increasing alarmingly in the world. In many countries the majority of young age people are sexually active before age of 20 and premarital sex is common among 15-19 years old [4]. World Health Organization reported in 2011 that

${ }^{*}$ Correspondence: honeyfikir1@gmail.com

School of Nursing, College of Health Sciences and Referral Hospital, Aksum University, Aksum, Ethiopia unsafe sex was second among the top ten risk factors in the global burden of all diseases caused globally [5].

Students of higher learning institutions are people with multiple socio-cultural grounds begin autonomous life at younger age for first time and they rush to a range of maladaptive high-risk extracurricular activities like alcohol use, substance and sexual abuse [6].

Study done in America on adolescent and young students showed that both casual and chronic substance users are more likely to engage in high-risk behaviors such as unprotected sex [7].

Sub- Saharan Africa remains most severely affected with nearly one in every 20 adults $4.9 \%$ living with HIV and accounting for $69 \%$ of the people living with HIV worldwide [8]. Different studies also revealed that young adults in Sub Saharan Africa were also tend to engage in having multiple sexual partner, concurrent sexual partners and unprotected sexual intercourse $[9,10]$.

Adolescents represent a huge segment of potentially vulnerable population in Ethiopia and an 
increasing number of them are involved in unsafe sexual practices and hence face undesired health outcomes such as unplanned pregnancy, too early childbirth, unsafe abortion and sexually transmitted disease $[11,12]$. There are evidences that show that some adolescents and young adults, who are left in the care of siblings without consistent adult supervision, have increased opportunities for sexual activity [13].

There are limited evidences on risk sexual behavior which is the focus this study. Therefore, the aim of this study is to assess the prevalence of risky sexual behavior among Aksum University students.

\section{Main text}

\section{Study area}

The study was conducted at Aksum University, Shire Campus which is one of the three campuses of Aksum University. It is located in northern Ethiopia, northwest zone of Tigray regional State, around $1078 \mathrm{kms}$ from Addis Ababa, the capital city of Ethiopia and $60 \mathrm{~km}$ from the main campus, Aksum. The research was conducted from April 1 to May 1, 2017.

\section{Study design}

Institutional based cross sectional study design was conducted.

\section{Sample size}

A total of 313 samples were calculated using a single population proportion formula by assuming $5 \%$ marginal error and $95 \%$ confidence interval $(\sigma=0.05)$ and prevalence of the risk sexual behavior 31.4\% [14] and by adding $10 \%$ of non-response rate.

\section{Sampling technique}

Three departments were selected by lottery method. Then the allocated sample was proportionally distributed to the selected departments and year of studies based on number of students. Finally students were selected from each selected departments and year of study by simple random sampling method by taking list of students which belongs to selected departments of all years from the office of the registrar.

\section{Data collection instrument and techniques}

A structured questionnaire was adopted and adapted from WHO sexual and reproductive health questioners and after review of relevant literatures and arranged according to particular objective it can address $[15,16]$. Before actual data collection, the tool was pre-tested in Adigrat University. Two days training was given to all data collectors and supervisors prior to pretesting. Eight data collectors who had completed diploma in midwife were recruited. The data was collected through selfadminister questionnaire.

\section{Data processing and analysis}

Data was analyzed using SPSS by the principal investigators. Frequency and percentage of each variable is presented using tables and figures.

\section{Ethical consideration}

Ethical approval was obtained from the college of the health science and referral hospital office of quality assurance enhancement. Permission to carry out this study was obtained from Aksum University of Shire Campus administration. Once permission was obtained from responsible body and written informed consent was asked from participants.

\section{Results}

Sociodemographic characteristics

Majority the respondents were males in sex and orthodox follower in religion. Majority of the respondents' age ranges from 21 to 23 years. More than half of the respondents are from rural. Concerning ethnicity, majority were Tigray followed by, Amhara. With regard to monthly income, majority earns greater than 300 ETB (Table 1).

\section{Substance use}

The Substance use by respondents was assessed with respect to drinking alcohol, chewing chat and smoking cigarette. This study finding showed that from the total respondents about $46.7,14.3$, and $16.8 \%$ of the respondents reported they had experienced drinking alcohol, chewing chat, and smoking cigarette respectively (Table 2).

\section{Sexual practice}

Out of the total respondents, 174 (60.6\%) of students had sexual experience. From the total respondents who had practiced sexual intercourse 66 (37.9\%) of them reported that their first sexual intercourse was before age of 18 years while $89(51.2 \%)$ of them had their first sex at above or equal to 18 years. All of the respondents with sexual experience 174 (100\%) has practiced vaginal sex, followed by anal and oral in which 6.3 and $5.2 \%$ respectively (Table 2).

\section{Premarital sex and contraceptive use}

From the study participants nearly half $(45.0 \%)$ accept (agreed) with premarital sexual practice. Among those who had sexual intercourse more than half 95 (54.6\%) 
Table 1 Shows sociodemographic characteristic of respondents among Aksum University, Shire Campus regular students, Shire Town, May, 2017 ( $n=287$ )

\begin{tabular}{|c|c|c|c|c|}
\hline S. no & Variables & Categories & Frequency $(n=287)$ & Percentage \\
\hline \multirow[t]{2}{*}{1} & Sex & Male & 171 & 59.6 \\
\hline & & Female & 116 & 40.4 \\
\hline \multirow[t]{4}{*}{2} & Age & $18-20$ & 40 & 13.9 \\
\hline & & $21-23$ & 156 & 54.9 \\
\hline & & $24-26$ & 75 & 26.4 \\
\hline & & $\geq 27$ & 16 & 5.6 \\
\hline \multirow[t]{2}{*}{3} & Previous place of residence & Urban & 137 & 47.7 \\
\hline & & Rural & 150 & 52.2 \\
\hline \multirow[t]{4}{*}{4} & Religion & Orthodox & 203 & 71.0 \\
\hline & & Muslim & 46 & 16.0 \\
\hline & & Protestant & 32 & 11.0 \\
\hline & & Others & 6 & 2.0 \\
\hline \multirow[t]{2}{*}{5} & Monthly income of the respondents & $\leq 300$ (ETB) & 126 & 43.9 \\
\hline & & $>300$ (ETB) & 161 & 56.1 \\
\hline \multirow[t]{5}{*}{5} & Occupation of mother & Housewife & 174 & 60.6 \\
\hline & & Employed & 33 & 11.5 \\
\hline & & Merchant & 24 & 8.4 \\
\hline & & Farmer & 52 & 18.1 \\
\hline & & No mother & 4 & 1.4 \\
\hline \multirow[t]{3}{*}{6} & Parents income per month & $<2000$ ETB & 44 & 15.3 \\
\hline & & 2000-3000 ETB & 89 & 31.0 \\
\hline & & $>3000$ & 154 & 53.7 \\
\hline \multirow[t]{5}{*}{7} & Ethnicity & Tigray & 124 & 43.0 \\
\hline & & Amara & 98 & 34.0 \\
\hline & & Oromia & 34 & 12.0 \\
\hline & & Somali & 17 & 6.0 \\
\hline & & Others & 14 & 5.0 \\
\hline
\end{tabular}

reported they had used one of the contraceptive methods at the time of their first sexual intercourse (Table 2).

\section{Condom use}

From sexually active 174 students, 103 (59.2\%) had used condom at least once in their life time during sexual intercourse. Among those above three quarter (83.5\%) were identified as using condom inconsistently (Table 2).

\section{Reason for initiation of first sex}

Respondents were asked about the main reasons for initiation of sex, and majority of the respondents were based on personal desire 107 (61.5\%). They initiate sexual intercourse based on their willingness like, fail in love, promising word from partner for marriage, curiosity or to see what it is, whereas $67(38.5 \%)$ initiated without their willing like, peer pressure 37 (21.3\%), influence of alcohol 17 (9.6), economic problem $8(4.6 \%)$, influence of chat or drug $3(1.7 \%)$, and others 2 (1.2\%) (Table 3$)$.

\section{Discussion}

Even though assessment of risky sexual behavior is somewhat challenging, particularly when adolescents and young adults are involved, this is the only available window to assess the risk sexual behavior in the study area. Similarly young adults and adolescents are the main risky group and are higher proportion, this finding gives clue for policy makers and higher officials to take some measures on the specific finding.

This study revealed that $60.6 \%$ of respondents ever had sexual activity. This finding is higher than the findings from Jimma and Haramaya University, in which (26.9\%) and $(33.5 \%)$ of students ever had sexual intercourse, respectively $[17,18]$. This might be partly due to difference in the study time and there is also slight difference in age.

In this study, about $37.9 \%$ of the respondents had experienced premarital sex before the age of 18 years. This finding is lower than the finding from study conducted 
Table 2 Sexual history, contraceptive, substance and condom use among respondents of Aksum University Shire Campus, undergraduate students, Northern Ethiopia, May, 2017, $(n=287)$

\begin{tabular}{|c|c|c|c|}
\hline Variables & Categories & Frequency & Percent \\
\hline \multirow[t]{2}{*}{ Ever had sexual intercourse } & Yes & 174 & 60.6 \\
\hline & No & 113 & 39.4 \\
\hline \multirow[t]{5}{*}{ With whom first sex was made } & Boy or girl friend & 121 & 69.5 \\
\hline & Stranger & 13 & 7.5 \\
\hline & Relatives & 11 & 6.3 \\
\hline & Sex worker & 12 & 6.9 \\
\hline & Don't know & 17 & 9.8 \\
\hline \multirow[t]{3}{*}{ Type of sex made } & Vaginal & 174 & 100.0 \\
\hline & Anal & 11 & 6.3 \\
\hline & Oral & 9 & 5.2 \\
\hline \multirow[t]{3}{*}{ Age at first sex } & $<18$ & 66 & 37.9 \\
\hline & $>18$ & 89 & 51.2 \\
\hline & Don't remember & 19 & 10.9 \\
\hline \multirow{2}{*}{$\begin{array}{l}\text { Number of sexual partners } \\
\text { over life time }\end{array}$} & One & 62 & 35.6 \\
\hline & More than one & 112 & 64.4 \\
\hline \multirow[t]{2}{*}{ Accept premarital sex practice } & Yes & 129 & 45.0 \\
\hline & No & 158 & 55.0 \\
\hline \multirow[t]{2}{*}{ Condom use } & Yes & 103 & 59.2 \\
\hline & No & 71 & 40.8 \\
\hline \multirow[t]{3}{*}{ Frequency of condom use } & Always & 47 & 16.5 \\
\hline & Most of the time & 92 & 32.0 \\
\hline & Some times & 148 & 51.5 \\
\hline \multirow{2}{*}{$\begin{array}{l}\text { Contraceptive usage among } \\
\text { started sex }\end{array}$} & Used & 95 & 54.6 \\
\hline & Not used & 79 & 45.0 \\
\hline \multirow[t]{2}{*}{ Drinking alcohol } & Yes & 134 & 46.7 \\
\hline & No & 153 & 53.3 \\
\hline \multirow[t]{2}{*}{ Smoking cigarette } & Yes & 48 & 16.7 \\
\hline & No & 239 & 83.3 \\
\hline \multirow[t]{2}{*}{ Chewing chat } & Yes & 41 & 14.2 \\
\hline & No & 246 & 85.0 \\
\hline
\end{tabular}

Table 3 Reasons for initiation of first sex in undergraduate students of Aksum University Shire Campus, Northern Ethiopia, May, 2017, ( $n=287$ )

\begin{tabular}{llll}
\hline Variables & Categories & Frequency & Percent \\
\hline $\begin{array}{l}\text { The main reason to } \\
\text { start sexual inter- } \\
\text { course at first time }\end{array}$ & $\begin{array}{l}\text { Desire to sexual experi- } \\
\text { ment }\end{array}$ & 107 & 61.5 \\
& $\begin{array}{l}\text { Peer-pressure } \\
\text { Influence of alcohol }\end{array}$ & 37 & 21.3 \\
& $\begin{array}{l}\text { Influence of chat or } \\
\text { drug }\end{array}$ & 3 & 9.6 \\
& $\begin{array}{l}\text { Economic problem } \\
\text { Don't know }\end{array}$ & 8 & 1.7 \\
& & 2 & 4.6 \\
\hline
\end{tabular}

among male college students of Kathmandu Nepal, showed that about $63.7 \%$ students were had sex before the age of 18 [19]. This might be due to the difference in awareness and cultural value of the respondents towards disadvantage of premarital sex and most sexual practice in Ethiopia is hidden or private domain. More over there is also difference in age distribution of the study subjects.

This study also found that Condom utilization at the time of intercourse among who had sexual intercourse was about $59.2 \%$, which is consistent with a study done in Jimma University which revealed that $69.1 \%$ utilized condom [1]. This might be due the similarity in accessibility of condom freely. This is also comparable with a study done in Ugandan universities which revealed that $50.0 \%$ utilized condom [20]. This may be due to the countries economical status and geographical location.

However, this study showed that the prevalence of inconsistent condom use was $83.5 \%$ despite the expectation of prevention awareness among university students; the prevalence is higher as compared to a study done in United States of America which shows that $64.0 \%$ of participants use condom inconsistently [21]. This might be due the magnitude of causal sexual practice and the difference in attitude of the respondents for different peoples, which indicates inadequacy of knowledge about reproductive health risks including HIV/AIDS, STI, unwanted pregnancy and its complications which have grave consequences on the students themselves and country as whole.

In this study $64.4 \%$ of study participants have more than one sexual partner which is more than twice than a study done in Haramaya and Jimma Universities, in which 11.5 and $28.3 \%$ had multiple sexual partners respectively $[17,18]$. When we compare it from abroad, it is above twice from the study done in Uganda in which $24.0 \%$ of the participants have more than one sexual partner [20]. This difference may be due to lack of awareness on the disadvantage of having multiple sexual partners and lack of youth reproductive health services. Similarly the study difference may be related with period of study.

Moreover, the study revealed that nearly half about $46.7 \%$ of the participants uses alcohol which is comparable with a study done in Haramaya University in which $41.7 \%$ uses alcohol, but the prevalence of chat chewing is lower than by half (14.3\%) from the study conducted in Haramaya University in which $30.3 \%$ of study participants uses chat [17]. This may be due to the cultural background of the study area and the accessibility of the substance respectively. Since chat is accessible in Harramaya but not in Aksum university.

In this study from the total of those participants with sexual activity the reason to start sexual intercourse was 
personal desire (61.5\%) which is higher than the study done in Zambia in which $48.0 \%$ of the participants were due to personal desire. Secondly, peer pressure was the second most important factor to start sex (21.3\%) which is comparable with the study done in Zambia in which $18.0 \%$ of the participants were practicing due to peer pressure [22]. This result may be an indicator for the influence of peer pressure and the need of awareness creation on friendship.

In this study $6.9 \%$ of the participants have their first sex with commercial sex worker which is lower than the study done in Haramaya University in which $16.3 \%$ of the participants have their first sex with commercial sex workers [17]. This may be due to limited number of bars, coffee houses and commercial sex workers.

For many times, interventions in the universities have focused on abstinence as policy. But as we have seen in this study $60.6 \%$ have already been in sexual activity in which abstinence by itself does not work. Again $64.4 \%$ ever had a practice of sex with multiple sexual partners and $83.5 \%$ use condom inconsistently. This shows as limiting sexual practices and not availing condom and other services do not hamper the students from performing sexual intercourse anywhere else unless their behavior is modified.

\section{Conclusion and recommendations}

Significant segment of students have risk sexual behaviors which increase individuals' risk of acquiring HIV/ AIDS. Substance use and peer pressure were revealed as predisposing factors for the existence of sexual risk behaviors. Unless appropriate age and institutional targeted interventions exist, certain behaviors can place the university students at greater risk of HIV infection and Sexually transmitted disease. So, universities should target to ensure healthy behavioral modification with availing necessary services like condom and contraceptive.

\section{Limitation}

There is a possibility of both under reporting of risk sexual behavior, because study the topic by itself assesses personal and sensitive issues related to sexuality.

\section{Abbreviations}

HIV: human immunodeficiency virus; AIDS: acquired immunodeficiency virus; STI: sexually transmitted infection; STDs: sexually transmitted diseases; WHO: World Health Organization; ETB: Ethiopian Birr.

\section{Authors' contributions}

AK conceived and designed the study, analyzed the data and wrote the manuscript. $\mathrm{HG}$ and $\mathrm{BM}$ involved in data analysis, drafting of the manuscript and advising the whole research paper $\mathrm{HG}$ also were involved in the interpretation of the data and contributed to manuscript preparation. All authors read and approved the final manuscript.

\section{Acknowledgements}

We would like to thank all study participants and data collectors for their contribution in success of our work.

\section{Competing interests}

This manuscript maintains no competing financial interest declaration from any person or organization, or non-financial competing interests such as political, personal, religious, ideological, academic, intellectual, commercial or any other.

\section{Availability of data and materials}

The data sets used and analyzed during the current study available from the corresponding author on reasonable request.

\section{Consent to publish}

Not applicable.

\section{Ethics approval and consent to participate}

Ethical clearance was secured from the Aksum University, College of Health Science research review committee. Respondents were well informed about the purpose of the study, and information was collected after full oral and written consent from participants aged 18 years and more, but age less than 18 year from the guardian. Information was recorded anonymously and confidentially, and beneficence was assured throughout the study period.

\section{Funding}

There is no funding for this research. All cost of data collection and analysis were covered by the authors.

\section{Publisher's Note}

Springer Nature remains neutral with regard to jurisdictional claims in published maps and institutional affiliations.

Received: 18 December 2017 Accepted: 23 January 2018

Published online: 31 January 2018

\section{References}

1. Leventhal AM, et al. Association of electronic cigarette use with initiation of combustible tobacco product smoking in early adolescence. JAMA. 2015:314(7):700-7.

2. Molla M, Berhane Y, Lindtjørn B. Traditional values of virginity and sexual behaviour in rural Ethiopian youth: results from a cross-sectional study. BMC Public Health. 2008;8(1):9.

3. Chapin KC. Molecular tests for detection of the sexually-transmitted pathogens Neisseria gonorrhoeae and Chlamydia trachomatis. Med Health Rhode Island. 2006;89(6):202.

4. UNICEF, J.U.N.P.o. HIV/AIDS, W.H. Organization. Young people and HIV/ AIDS: opportunity in crisis. 2002. The Stationery Office.

5. Harvey SM, Beckman LJ. Alcohol consumption, female sexual behavior and contraceptive use. J Stud Alcohol. 1986;47(4):327-32.

6. Kebede $\mathrm{D}$, et al. Khat and alcohol use and risky sex behaviour among in-school and out-of-school youth in Ethiopia. BMC Public Health. 2005;5(1):109

7. DiClemente RJ, et al. A prospective study of psychological distress and sexual risk behavior among black adolescent females. Pediatrics. 2001;108(5):e85.

8. Deyessa N, Tesfaye G. Intention to use condom among students in Agena preparatory school, Guraghe Zone, Ethiopia: with the application of health believe model. Arch Public Health. 2013;71(1):23.

9. Gavin $\mathrm{L}$, et al. Factors associated with HIV infection in adolescent females in Zimbabwe. J Adolesc Health. 2006;39(4):596. e11-8.

10. Chapman $R$, et al. Do behavioural differences help to explain variations in HIV prevalence in adolescents in sub-Saharan Africa? Trop Med Int Health. 2010;15(5):554-66

11. Tesso DW, Fantahun MA, Enquselassie F. Parent-young people communication about sexual and reproductive health in E/Wollega zone, West Ethiopia: Implications for interventions. Reprod Health. 2012;9(1):13. 
12. Tilahun $M$, Ayele $G$. Factors associated with age at first sexual initiation among youths in Gamo Gofa, south west Ethiopia: a cross sectional study. BMC Public Health. 2013;13(1):622.

13. Adefuye AS, et al. HIV sexual risk behaviors and perception of risk among college students: implications for planning interventions. BMC Public Health. 2009;9(1):281.

14. Soboka B, Kejela G. Assessment of risky sexual behaviors among Arba Minch University Students, Arba Minch Town, Snnpr, Ethiopia. J Child Adolesc Behav. 2015:3(2):189-95. https://doi. org/10.4172/2375-4494.1000189

15. Khan KS, et al. WHO analysis of causes of maternal death: a systematic review. Lancet. 2006;367(9516):1066-74.

16. Regassa N, Kedir S. Attitudes and practices on HIV preventions among students of higher education institutions in Ethiopia: the case of Addis Ababa University. Educ Res. 2011;2:828-40.

17. Derese A, Seme A, Misganaw C. Assessment of substance use and risky sexual behavior among Haramaya University students, Ethiopia. Sci J Public Health. 2014;2(2):102-10.
18. Tura G, Alemseged F, Dejene S. Risky sexual behavior and predisposing factors among students of Jimma University, Ethiopia. Ethiop J Health Sci. 2012;22(3):170-80

19. Imaledo JA, Peter-Kio OB, Asuquo EO. Pattern of risky sexual behavior and associated factors among undergraduate students of the University of Port Harcourt, Rivers State, Nigeria. Pan Afr Med J. 2012;12:97.

20. Commission, L.V.B. HIV sero-behavioural study in six Universities in Uganda. 2010.

21. Certain HE, et al. Condom use in heavy drinking college students: the importance of always using condoms. J Am Coll Health. 2009:58(3):187-94.

22. Awang $\mathrm{H}$, et al. Knowledge of sexually transmitted diseases and sexual behaviours among Malaysian male youths. J Biosoc Sci. 2014;46(2):214-24.

\section{Submit your next manuscript to BioMed Central and we will help you at every step:}

- We accept pre-submission inquiries

- Our selector tool helps you to find the most relevant journal

- We provide round the clock customer support

- Convenient online submission

- Thorough peer review

- Inclusion in PubMed and all major indexing services

- Maximum visibility for your research

Submit your manuscript at www.biomedcentral com/submit 